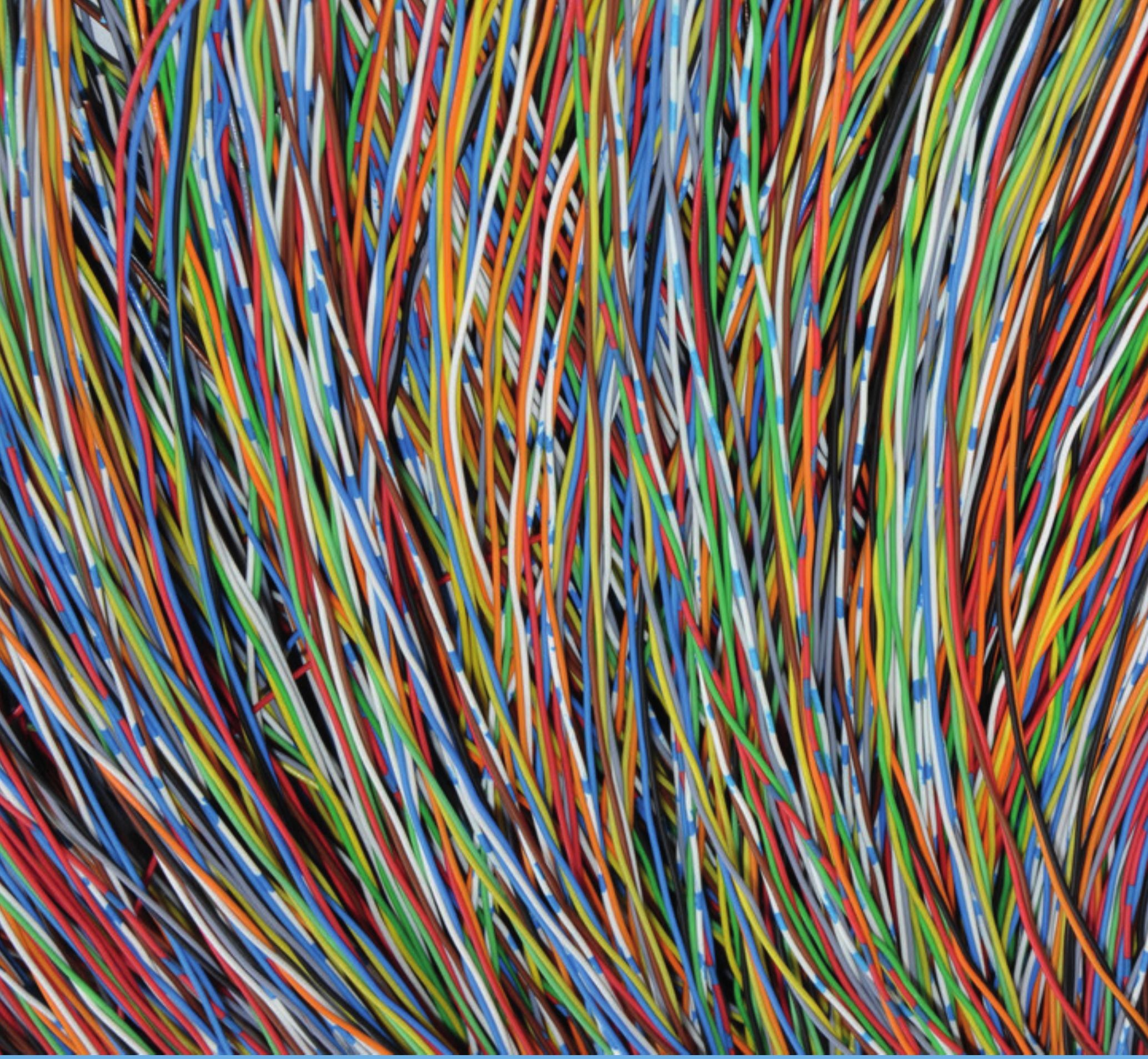

Exploring the potential of blockchain

technology to collect finances from remittances

for social entrepreneurs in the agrifood sector

Jaclyn Bolt, Ingrid Coninx

$\square \quad \begin{aligned} & \text { WAG ENINGEN } \\ & \text { UNIVERSITY \& RESEARCH }\end{aligned}$ 



\section{Exploring the potential of blockchain technology to collect finances from remittances for social entrepreneurs in the agrifood sector}

Jaclyn Bolt, Ingrid Coninx

Wageningen Environmental Research

Wageningen, January 2019

Reviewed by:

Tineke de Boer, Researcher (Wageningen Environmental Research)

Approved for publication:

Corine van As, Teamleader of Regional Development and Spatial Use

Report 3083

ISSN 1566-7197 
Bolt, J., Coninx I., 2019. Exploring the potential of blockchain technology to collect finances from remittances for social entrepreneurs in the agrifood sector. Wageningen, Wageningen Environmental Research, Report 3083. 36 pp.; 2 fig.; 2 tab.; 28 ref.

Abstract NL Afrikaanse sociale ondernemers die werken aan het verbeteren van voedselzekerheid in hun regio hebben vaak lastig toegang tot financiering. Deze studie verkent wat de potentie is van blockchain technologie om geld van de diaspora in Nederland naar sociale ondernemers in Afrika te sturen. Deze studie verkent de uitdagingen van de huidige internationale transfersystemen en de wensen en bereidheid van diaspora en sociale ondernemers om gebruik te maken van blockchain technologie. De conclusie is dat de huidige systemen heel wat uitdagingen hebben die mogelijks via blockchain verbetert kunnen worden. Echter, de meerwaarde van zo'n systeem voor de case 'Kenya' is beperkter dan in andere Afrikaanse landen omwille van de aanwezigheid van snelle online betaalsystemen. Ook zal het een uitdaging worden om de bereidheid van sociale ondernemers om bepaalde informatie vrij te geven te verbinden met de informatiebehoeften van de diaspora. Wanneer organisaties blockchain technologie willen inzetten, dan raden we een aanpak van trial en error aan om de blockchain technologie geleidelijk aan te ontwikkelen, te testen en toe te passen.

Abstract UK African social entrepreneurs improving food security in their community are faced with difficulties to get access to finance. This study explores the role of blockchain technology to ease access to funding by social entrepreneurs to remittances from diaspora in the Netherlands. Therefore, the study has analysed the challenges of the current international transfer systems and the preferences and willingness of diaspore and social entrepreneurs to make use of the blockchain technology. The conclusion is that current systems can be improved by blockchain technology. However, the added value of blockchain for the specific case of Kenya might be low given the large option of online ways to transfer money. Furthermore, the information needs from diaspora needs to be matched with the willingness to reveal information by social entrepreneurs. If there are ambitions to make use of blockchain, we recommend to explore the application of blockchain technology on remittances via a process of trial and error.

Keywords: Blockchain, remittances, Kenya, social entrepreneurs, food security, information provision.

The pdf file is free of charge and can be downloaded at https://doi.org/10.18174/546223 or via the website www.wur.nl/environmental-research (scroll down to Publications - Wageningen Environmental Research reports). Wageningen Environmental Research does not deliver printed versions of the Wageningen Environmental Research reports.

2019 Wageningen Environmental Research (an institute under the auspices of the Stichting Wageningen Research), P.O. Box 47,6700 AA Wageningen, The Netherlands, $\mathrm{T}+31(0) 3174807$ 00, www.wur.nl/environmental-research. Wageningen Environmental Research is part of Wageningen University \& Research.

- Acquisition, duplication and transmission of this publication is permitted with clear acknowledgement of the source.

- Acquisition, duplication and transmission is not permitted for commercial purposes and/or monetary gain.

- Acquisition, duplication and transmission is not permitted of any parts of this publication for which the copyrights clearly rest with other parties and/or are reserved.

Wageningen Environmental Research assumes no liability for any losses resulting from the use of the research results or recommendations in this report.

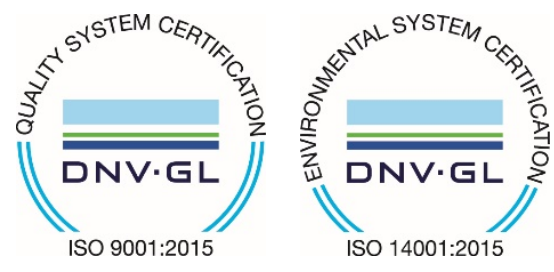

In 2003 Wageningen Environmental Research implemented the ISO 9001 certified quality management system.

Since 2006 Wageningen Environmental Research has been working with the ISO 14001 certified environmental care system.

By implementing the ISO 26000 guideline, Wageningen Environmental Research can manage and deliver its social responsibility.

Wageningen Environmental Research report 3083 | ISSN 1566-7197

Photo cover: Shutterstock 


\section{Contents}

$\begin{array}{ll}\text { Verification } & 5\end{array}$

$\begin{array}{ll}\text { Introduction } & 7\end{array}$

$\begin{array}{ll}\text { Remittances and diaspora } & \mathbf{8}\end{array}$

2.1 Types of remittances $\quad 8$

2.2 What is the amount of global remittances?

$\begin{array}{ll}2.3 \text { Challenges of remittances } & 10\end{array}$

2.3.1 The high transaction costs 10

$\begin{array}{ll}2.3 .2 \text { Lack of transparency } & 10\end{array}$

2.3.3 Potential distorting effect in home countries 10

2.3.4 Risk of losing money 11

2.3.5 Time consuming 11

2.4 The opportunities of remittances 11

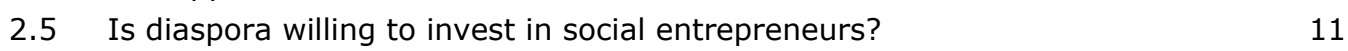

3

Ways of transferring money $\quad 13$

3.1 Banks 13

3.2 Transferwise 13

$\begin{array}{lll}3.3 & \text { Paypal } & 14\end{array}$

3.4 Money Transfer Organisations $\quad 14$

$\begin{array}{lll}3.5 & \text { Comparative summary of transaction costs } & 15\end{array}$

$\begin{array}{lll}3.6 & \text { Informal systems } & 15\end{array}$

$\begin{array}{lll}3.7 & \text { Views on international money transfer } & 16\end{array}$

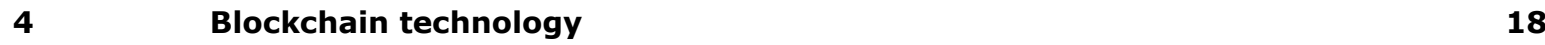

4.1 What is blockchain technology?

$\begin{array}{lll}4.2 & \text { Blockchain and cryptocurrencies } & 18\end{array}$

4.2.1 Modalities to use bitcoin for remittances 19

4.3 Decentralised and centralised blockchain applications for remittance 20

4.3.1 Decentralised blockchain $\quad 21$

4.3.2 Blockchain in a conventional, centralised process $\quad 22$

5 Social entrepreneurs in the agrifood sector Sub-Saharan Africa 25

$\begin{array}{lll}5.1 & \text { Social entrepreneurs in the agrifood sector } & 25\end{array}$

$\begin{array}{lll}5.2 & \text { Access to finance } & 25\end{array}$

5.3 Views on blockchain technology as a way to receive funding and related

$\begin{array}{lll}5.4 & \text { Existing platforms to finance social entrepreneurs } & 29\end{array}$

6

$\begin{array}{ll}\text { Conclusion } & 30\end{array}$

$\begin{array}{ll}\text { References } & 33\end{array}$

$\begin{array}{lll}\text { Annex } 1 \quad \text { List of interviewed persons } & 35\end{array}$ 



\section{Verification}

Report: 3083

Project number: 5200044511

Wageningen Environmental Research (WENR) values the quality of our end products greatly. A review of the reports on scientific quality by a reviewer is a standard part of our quality policy.

Approved reviewer who stated the appraisal,

position: Researcher

name: Tineke de Boer

date: $\quad$ April 2021

Approved team leader responsible for the contents,

name: Corine van As

date: $\quad$ April 2021 


\section{Introduction}

This report aims to explore the use of blockchain technology to financially support social entrepreneurs that are improving food security in Sub-Saharan Africa. The three main elements in this report are: social entrepreneurs, remittances and blockchain technology.

Social entrepreneurs are doing business to solve social challenges. In Sub-Sharan Africa, a substantial group of social entrepreneurs are oriented to improve food security in their regions (Aalbers, Ten Hove, van der Pijl, 2019). One of the challenges of social entrepreneurs is to access finance to support setting up their business. Social enterprises usually require more time to achieve a return of their investment, compared to conventional entrepreneurs. Consequently, conventional financing sources such as loans from banks, are often not an option, because the social entrepreneurs have a high risk not being able to pay back their loans in the first years of launching their business. But also in the growth stage, social entrepreneurs are needing financial support.

It is known that diaspora annually send significant amounts of money back home, called 'remittances'. Remittances, being the transfer of money by an expatriate/migrant to his or her country of origin, play a considerably role to contribute to the sustainable development goals. Currently, worldwide, remittances make up for approximately 600 billion USD, which is more than three times greater than the funds involved in aid. Consequently, remittances play an increasingly large role in economies of developing countries and can make up a significant portion of a country's gross domestic product. This international money is transferred through different channels like transfer agencies such as Western Union and Money Gram, but also via online banking or via M-PESA (typical for Kenya).

The blockchain technology is starting to play an important role in the money transfer market. The technology follows the line of evolution of database technology and is regularly acknowledged for its impact on reducing transaction costs, creating better provenance and improving on traceability and transparency (Baker \& Steiner, 2015). Platforms facilitating money transfers through blockchain technology are emerging while formal established banks and money transfer organisations are looking into this innovation to determine its use for their current processes.

Considering and connecting the social entrepreneurs, remittances and blockchain technology, we want to get a better understanding on these new and innovative ways to support social entrepreneurs working in the agrifood sector to improve food security in Sub-Saharan Africa. Research questions are the following:

- What is the potential of funding coming from the remittances of the diaspora? (1.2)

- What are financial challenges when sending money? (1.3)

- What are the challenges of social entrepreneurs with regard to financial support?

- What are the views of the different stakeholders on the current challenges and the potential of block chain technology? (4.3)

- What are the conditions that diaspora (would) set, when transferring money to social entrepreneurs via blockchain?

- What information provision has to be part of the blockchain concept?

This exploration is done to support the SES4FOOD team and has focussed on Kenya. SES4FOOD stands for Social Entrepreneurship Support for Food security. This SES4FOOD team has mapped 21 social entrepreneurs in the agrifood sector and has engaged an active linking pin working in the region (https://socialfoodentrepreneurs.ushahidi.io/views/map). In this way, we had easily access to the network of social entrepreneurs in the agrifood sector. Furthermore, we interviewed key stakeholders like the diaspora (organisations), blockchain experts and crowdfunding experts. We organised two focus groups in Nairobi to explore barriers and opportunities of transferring money from diaspora to social entrepreneurs and the willingness to use blockchain. The first focus group included 7 Kenyans that are receiving remittances. The second focus group included 6 social entrepreneurs working on food security in Kenya. The focus groups took place on October 23, 2018 in Nairobi. 


\section{Remittances and diaspora}

\section{$2.1 \quad$ Types of remittances}

Remittances is the money that diaspora send back home. Within the realm of remittances, different categories exist depending on the source (IMF, 1977, 108-109, cited H. Smits 2005):

- Workers' remittances: transfers made by workers who lives abroad for more than a year;

- Migrants' transfers: the various flows of goods and financial assets that result to the net value from migration (due to change of residence) and corresponding to the net value of migrants' transfers (not including capital goods);

- Labour income: wages, salaries, and other compensations (in cash or in kind) received by people working abroad for less than twelve months.

Remittances may have different functions and can be spent differently (Durand, 2004; Smits, 2005):

- Remittance as wage or salary: this is sent by seasonal migrants to support close relatives that are left behind.

- Remittance as investment: these remittances may be sent during a trip or brought back upon return. They are associated with target-earners, migrants who make a few trips with a specific objective, such as saving money to buy land or build a home.

- Remittances as capital: this is money saved specifically to invest in a productive venture.

Remittances are used for education, health care, funerals land, construction of houses and day-to-day needs like food (interviews and focus group; Ratha et al. 2011).

\subsection{What is the amount of global remittances?}

It is not easy to have a complete overview of the actual remittances due to fragmented ways of sending money back home and due to the existence of informal systems. Some people use bank transfers and send a regular part of their salary home. Other use systems like Hawala, a system to transfer money based on trust. There are informal banking arrangements that allow transfer of funds without using formal financial institutions. These systems are not transparent and the remittances flows are consequently not documented.

World Bank is annually trying to assess the remittances flows and has estimated the total amount of remittances in 2016 at the level of USD 445.3 billion. This means an increase of about $51 \%$ since the year 2007 (IFAD, 2017). Most of this money is sent to Asia and the Pacific (USD 243.6 billion) and to smaller extent to Latin America and the Caribbean (USD 73.1 billion), Africa (USD 60.5 billion), Europe (USD 43.5 billion) and the East and Caucasus (USD 24.6 billion) (IFAD, 2017). European remittances are mainly going to countries in Eastern Europe.

In this report, we are mainly interested in remittances that are sent to Sub-Saharan Africa. In 2016, Nigeria (almost USD 19,000 million), Ghana and Senegal (each about USD 2,000 million), Kenya (USD 1,700 million) and Uganda (about USD 1,000 million) were among the top 5 countries that received the highest amount of remittances (IFAD, 2017). Ratha et al. (2011) has analysed the sources of remittances that are going to Sub-Saharan Africa. $28 \%$ of the remittances are coming from United States, $41 \%$ from Western Europe, $9 \%$ from Gulf Cooperation Council, $8 \%$ from other high income countries, $10 \%$ from within Africa and 3\% from other developing countries (Figure 1). 

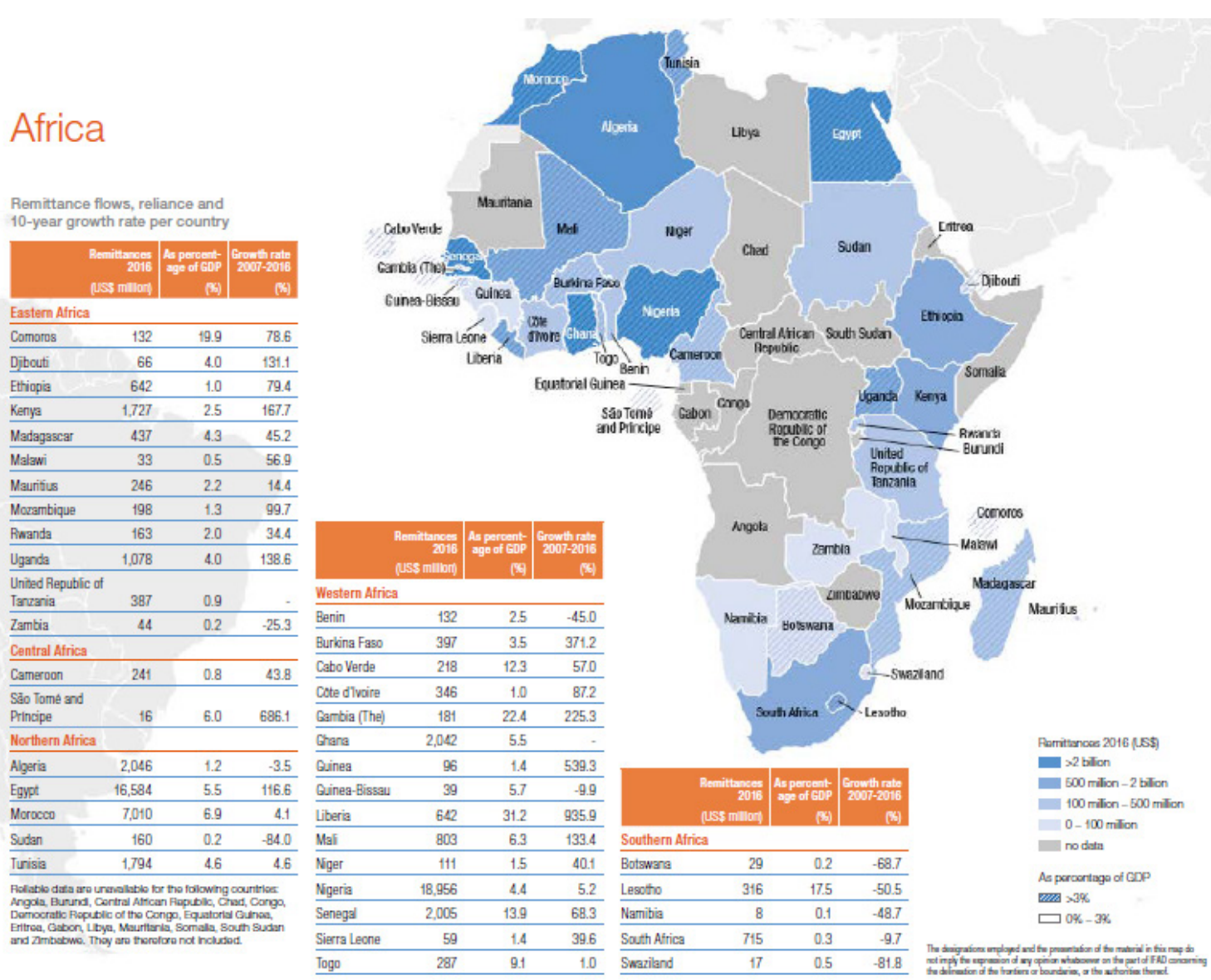

Figure 1 Remittance flows

Source: IFAD, 2017

The amount of remittances that is annually leaving the Netherlands is also assessed by the World Bank. In 2016, it was estimated at a level of about USD 7,500 million. This amount has increased over time, 2008 being a peak year (Figure 2).

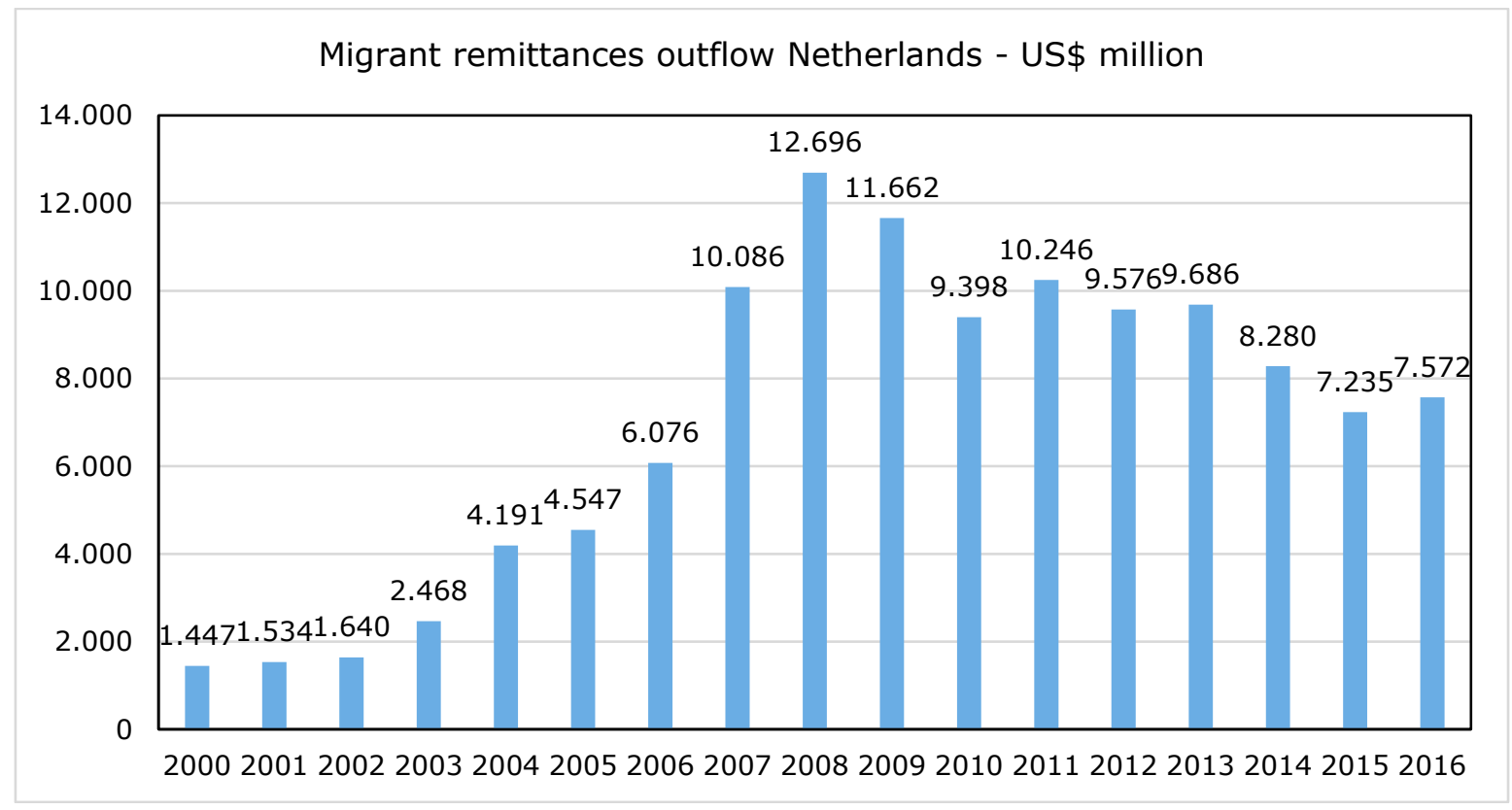

Figure 2 Migrant remittances outflow Netherlands

Source: World Bank, 2018 
Most of this money coming from the Netherlands is sent to Nigeria (165 million USD); Ghana (55 million

USD); South Africa (16 million USD); Kenya (14 million USD) and Ethiopia (11 million USD).

\subsection{Challenges of remittances}

\subsubsection{The high transaction costs}

The transaction costs for transferring money internationally are high. In 2004, member countries of G8 have committed to reduce the cost of remittance from 10 percent to 5 percent in five years, known as the $5 \times 5$ objective (IBRD 2014). Although transaction costs are decreasing, the global average is still not reached. In addition, the transaction costs between specific regions can largely differ. The "The Global Compact on safe, orderly and regular migration (2018)" also includes the goal to promote faster, safer and cheaper transfer of remittances and it is stated that transaction costs should be less than $3 \%$ by 2030 . The Compact also aims to optimize the transformative impact of remittances on the well-being of migrant workers and their families, as well as on the sustainable development of countries.

The International Fund for Agricultural Development (IFAD) has observed that since 2011, Africa has had the largest reduction in remittance transaction costs. The costs of remittance services in SubSaharan Africa have declined to $9,4 \%$, but are still the costliest in the world, in particular $29 \%$ above world average (Worldbank, 2018). Within Africa, transferring money between Angola and Namibia is most expensive. Transferring money from Côte d'Ivoire to Mali is least expensive.

What explains the high transaction costs? They relate to exchange rates, transfer fees and national taxes. Another explanation is the stronger standard for anti-money-laundering. Banks have restricted or terminated their relationships with Money Transfer Organisations (MTOs) because of this standard (KNOMAD 2017). Banks are nowadays facing 'know your customer' standards which come with a cost.

According to Cecchetti and Schoenholtz (2018), the reduction of the costs of small remittances to $5 \%$ should be feasible. A decrease in transaction costs will result in a total increase of remittances. The World Economic Forum (2015) estimates that a reduction of transaction costs for Sub-Saharan Africa to the global average would mean an extra 1.3 billion USD reaching the families in this region.

Ways to decrease transaction costs are (WEF, 2015; EBRD/IDA 2016):

1. Increase competition in global remittance market and raising awareness of migrants on the different remittances services.

2. Increase transparency and education on exchange rates, fees and taxes. A benchmark shows the average of the three lowest-cost remittance service providers in different regions, like Worldbank and Smart Remitter Target (SmaRT) have developed (IBRD/IDA 2016).

3. Encouragement of technological innovation by supporting emerging technologies.

4. Working on political pressure and willpower to reform these transactions.

\subsubsection{Lack of transparency}

Remittances flows are not transparent. Various systems are used, both formal as well as informal. It is mainly in the context of terrorism and money laundering that remittances are contested. Banks abide to follow anti-money laundering and anti-terrorism financing regulations and are allowed to take action when risk is suspected.

\subsubsection{Potential distorting effect in home countries}

In some cases, remittances are a lifeline for recipients. The recipients are able to buy food, shelter and education with this money. Remittances can become a problem when there is a too large difference between the people that do receive and people that do not receive remittances. There is a risk to distort the social and economic structures back home. It may create dependency, can increase local prices, exacerbate inequalities, put pressure on senders, and at the macro scale can even affect 
currency, can result in inflation, more privatisation of services that should be publicly delivered and it can destabilise weak economies (IOM, 2014).

\subsubsection{Risk of losing money}

One informal way to transfer money is by post. This way of transferring money was used in times before money transferring systems existed. Transferring money via post may come with a large risk to lose the money. The risk of losing money decreases when the money is transferred together with some goods (interview, 2018). People also risk losing the money when they travel with the cash they have received. They are at risk for robbery.

\subsubsection{Time consuming}

Formal transferring systems requires legitimation by ID and filling in required forms. That may take time, also regarding verification at the side of the receiver. Furthermore, people that live in rural areas sometimes have to travel to cities to receive the money. That may take up to a day. Transferring money internationally may take a few days before it arrives at the local bank account.

\section{$2.4 \quad$ The opportunities of remittances}

Remittances can play an important role in the sustainable development of developing countries (http://www.un.org/en/events/family-remittances-day/un-action.shtml). The large amounts of funds that enter a developing country can support its population to buy necessities, pay for health care and education. It may boost local economies and may even increase the creditworthiness of recipient countries (IOM, 2014). It can create impact at the household level, the community level and at the national level. The World Economic Forum (2015) emphasises the importance of the efficient remittances as driver of financial inclusion and gateway to banking and an important role for progress in economic growth, health and education.

Regarding investing remittances in social entrepreneurs in the agrifood sector, it can be expected that this will contribute to:

- SDG 2 - zero hunger: the social entrepreneurs may produce food or ease access to food for the local community. Access to better food will improve nutrition. Their activities may result in additional employment opportunities.

- SDG 5 - gender equality: remittances for female social entrepreneurs can result in more gender equality. It can contribute to transforming the economic role of women in society and in business.

- SDG 6 Clean water and sanitation; SDG 7 affordable and clean energy; SDG 12 Responsible consumption and production and SDG 13 Climate Action: depending on the type of business of the social entrepreneurs, the investments by remittances can contribute to these societal challenges.

\subsection{Is diaspora willing to invest in social entrepreneurs?}

With regard to our specific case that we explore, we are mainly interested to know if the diaspora is willing to revert remittances to social entrepreneurs to improve food security. From our interviews, we can conclude that diaspora and people working with organisations of diaspora are willing to invest in initiatives for social entrepreneurs in sub-Saharan Africa. These entrepreneurs might come from other countries than the diaspora' s home country. The interview respondents have indicated that they want to send remittances with the aim to reduce poverty, strengthen competences of local people, for agriculture or agricultural services, and for real estate. On the other hand, some interview respondents have indicated that they find it difficult to invest in Africa, mainly because they find it challenging to find a reliable person to invest in. 
The amount of investment might be increased when entrepreneurs are presented with the proper business information and business prospects. The interviews show that diaspora are interested in information like:

- return on investment

- the social aspect of the enterprise

- how the investment will help the entrepreneur

- the legitimacy of the founder or the entrepreneur

- whether the organisation is a cooperative

- the employment that will be created

- the poverty that will be reduced and other environmental benefits

- annual financial statements

- information about governance

- history of the company

- the involved team

- information about the product.

The information should be easily accessible, and the impact should be clear. Overall, getting trust that the investment will be well spend, is a very important element. Provision of the proper documents, and perhaps even guarantees, can help to mitigate the (perceived) risks. The diaspora does consider the transferred money as an investment.

Another suggestion to revert remittances to social entrepreneurs was that part of the monthly send remittances could go to social entrepreneurs. Where they would normally paying transaction costs to intermediary parties, they would consider alternative methods with lower transaction costs which could reserve a small percentage for the benefit of social entrepreneurs in sub-Saharan Africa. 


\section{Ways of transferring money}

This section will describe and compare the different ways to transfer money from the Netherlands to Sub-Saharan Africa. This section is based on the interviews, the focus groups and desk research information.

\section{$3.1 \quad$ Banks}

Transferring money is one of the core businesses of banks. In return, transfer costs have to be paid. When sending money internationally, there are three options: shared costs (both sender and receiver pay each half of the cost), sender pays costs or receive pays the costs. Banks are able to block money transfer to foreign accounts due to high standards (like 'know your customer' - KYC). Some people do not opt for transferring money via bank because of the high transactions costs and because the recipient may not have access to a bank or financial services in general.

Transferring costs can largely differ. Most Dutch banks charge $0.1 \%$ of the amount sent (minimum $€ 6$, maximum $€ 50)$ + an additional fee per country. In addition, it appears not to be possible to send money to any country. For sub-Saharan Africa, money transfer service is offered to Angola ( $€ 25)$, Botswana $(€ 25)$, Burundi $€ 25)$, Cameroon ( $€ 50)$, Kenya ( $€ 50)$, Mauritius ( $€ 15)$, Mozambique ( $€ 25)$, Namibia ( $€ 25)$, Uganda ( $€ 50)$, Reunion ( $€ 25)$, Tanzania ( $€ 25)$, Zambia $(€ 50)$, all other countries are $€ 50$.

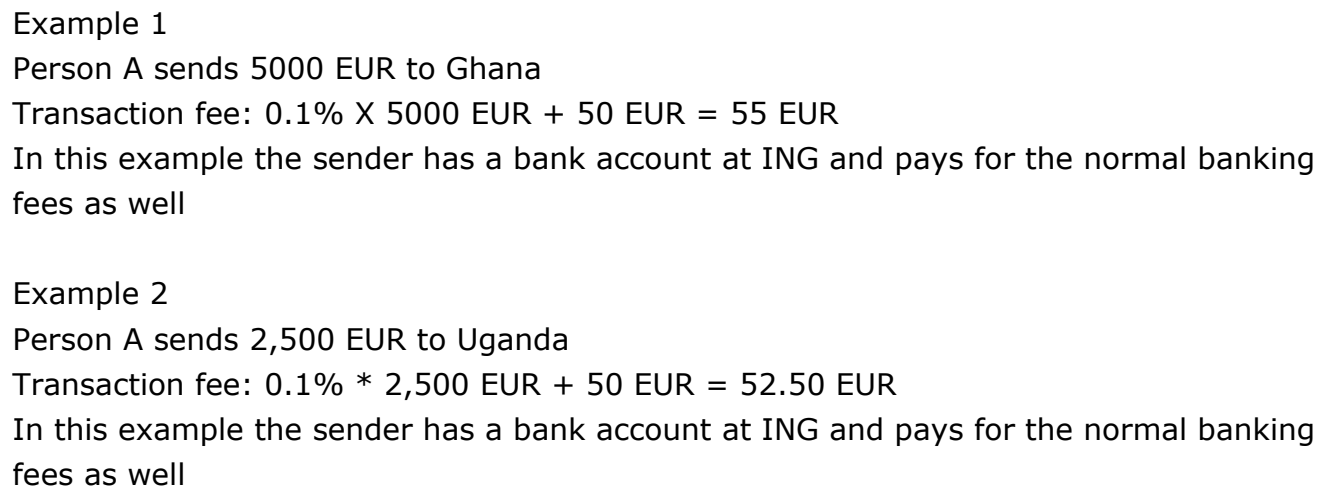

Banks are cautious to transfer money to countries with high-risk profiles. They carefully check the destination of the money and have to make sure that the Know Your Customer (KYC) is guaranteed and clear. In case they lack information on the KYC and they suspect a risk, the money cannot and will not be transferred by the bank. Furthermore, the transfer of money takes time, and may even take up to 3-5 days.

\subsection{Transferwise}

This is a system that keeps different currencies of respective countries. It provides a way to overcome losses due to exchange rate. Transferwise works as follows: the sender sends money from a Dutch account from Transferwise, who matches this amount with other users who want to make an exchange in the opposite direction. In other words, the receiver receives the money that is basically never internationally transferred. As a result, there are no currency exchange fees. Both the sender and receiver require internet. The costs exist of a fixed fee plus a percentage that is based on the source currency. 
In an example of sending 1000 EUR to Kenya, the fees are 8.94 EUR. The money can be sent to a bank account and in the case of Kenya for example, a significantly smaller sum can be sent to a M-PESA wallet. The money should arrive within the same day but can take up to two working days to convert funds.

\section{Example 1}

Person A sends 5000 EUR to Ghana

Transaction fee: $1.2 \% * 5000$ EUR +3 EUR $=62.25$ EUR

Example 2

Person A sends 2,500 EUR to Uganda

Not possible with Transferwise

\subsection{Paypal}

Money is transferred with the use of an email address and the receiver needs to have a Paypal account. Less credentials are needed. However, both sender and recipient must have access to the internet. Costs are between $0.3 \%$ and $1 \%$ plus 0.35 EUR per transaction, however when using a credit card, fees are between $3.4 \%$ and $7.4 \%$ and 0.35 EUR.

\section{Example 1}

Person A sends 5000 EUR to Ghana

Not possible with Paypal

\section{Example 2}

Person A sends 2,500 EUR to Uganda

It is not clear what the amount will be exactly (soft paywall)

But with costs between $0.3 \%$ and $1 \%$ this may vary between 7.85 EUR and 25.35 EUR

With the use of credit card this may vary between 85.35 EUR and 185.35 EUR

\subsection{Money Transfer Organisations}

In the Netherlands, the interests of intermediaries in the field of money transfers are represented by a union called: Nederlandse Vereniging van Geldtransactiekantoren (NVGTK). This union aims to generate and maintain a virtuous and reliable reputation. The following intermediaries are member of this union:

\begin{tabular}{|c|c|c|c|}
\hline Caleen Financial Services & Suri Change BV & $\begin{array}{l}\text { RIA Financial Netherlands } \\
\text { B.V. }\end{array}$ & Moneytrans Nederland BV \\
\hline $\begin{array}{l}\text { Exchange Corporation } \\
\text { Netherlands BV }\end{array}$ & WUPSIL & Pott Change Damrak BV & G.A.P Vassilopoulos \\
\hline $\begin{array}{l}\text { St. Nedsom Financial } \\
\text { Services }\end{array}$ & $\begin{array}{l}\text { Western Union services } \\
\text { Belgium }\end{array}$ & Exchange Corporation BV & Aftab Currency Exchange Ltd \\
\hline Sunro Change BV & MoneyGram International & $\begin{array}{l}\text { Small World Financial } \\
\text { Services }\end{array}$ & \\
\hline
\end{tabular}

Example 1 (MoneyGram money transfer)

Person A sends 5000 EUR to Ghana

Costs are 49.00 EUR, the receiver receives the funds in cash

When transferring money to a bank account, the fee is 3.00 EUR 
This is a rough estimation based on their website. They mention factors as location specific costs, foreign exchange rates and other factors might influence the price.

Example 2

Person A sends 2,500 EUR to Uganda

When the receiver picks up a cash amount, the fee is 62 EUR

It is not possible to send the amount to a bank account

\subsection{Comparative summary of transaction costs}

With regards to the applied instruments, the difference of costs in funding a remittance transaction was the following in 2017 (World Bank 2017);

- Mobile money $(4.21 \%)$

- Debit/Credit Card (6.01\%)

- Cash (7.09\%)

- Bank Account (7.04\%)

This can be further differentiated. Sending a remittance to different receiving instruments leads to different costs in receipt by;

- A bank account within the same bank (5.68\%)

- A bank account by a different bank (7.52\%)

- A mobile wallet (5.3\%)

- Cash $(6.63 \%)$

The most popular ways of conducting a remittance in 2017 was cash to cash which is also the costliest procedure (World Bank 2017).

\subsection{Informal systems}

Next to formal remittances through official and recorded channels, informal remittances (also known as 'hawala') exist. These channels are unrecorded and the total amount of remittances is therefore unknown. People using informal channels often experience these channels as being faster and more convenient than formal channels. However, both channels include transaction costs.

The interviewed groups in the Netherlands and Kenya explained various ways in which informal remittances can be organised.

The first way is via persons they know in their home country that have an international company with a Dutch bank account. The diaspora deposits an amount on this account and the entrepreneur pays this amount in home country in the local currency. The sender is not required to pay transaction costs and according to our interviewees, the currency differences are negligible. The entrepreneur often needs to buy supply in Europe requiring Euros. Through this remittance channel, they no longer need to buy euros, bypassing currency exchange costs. This money usually arrives within the same day and the diaspora will notify their relatives back home through a text or WhatsApp message after which the entrepreneur transfers the money to the bank account or provide the cash. This method also works the other way around when diaspora know a person in the Netherlands with an import/export business engaged in business in their home country They will buy products from for example Ghana for the Netherlands where they pay in Euros and the entrepreneur will pay back in local currency. However, not all diaspora have access to such acquaintances.

A second way is to make use of a middleman. These are people travelling back and forth between the home country and the Netherlands and they take some cash amounts for a small fee. This method seems unreliable and risky. Some interviewees have mentioned situations where the money disappears. Another bottleneck is that they need to meet people at locations that may not be convenient. Furthermore, travelling with these amounts makes diaspora wary for their family becoming exposed to robberies in transportation. 
A third way is to leave a larger amount of money with a local business close to family at home.

Whenever a family member requests an amount, the business owner will contact via message text the diaspora in the Netherlands for approval and will disburse the money.

\subsection{Views on international money transfer}

We asked the focus group of 7 people that are receiving remittances about their experiences with international money transfer systems.

Table 1 Summary of experiences about international money transfers by focus group participants in Kenya

\begin{tabular}{|c|c|c|c|c|}
\hline Way of transferring & Procedure & Convenience & Time needed & Costs \\
\hline M-Pesa & $\begin{array}{l}\text { - Transferred directly } \\
\text { to cell phone }\end{array}$ & $\begin{array}{l}\text { Easy } \\
\text { But limitation in terms - } \\
70000 \text { KES }\end{array}$ & & $\begin{array}{l}\text { Challenge is the rate of } \\
\text { taxation in the country } \\
\text { - costly due to Kenyan } \\
\text { taxation laws }\end{array}$ \\
\hline Western Union & $\begin{array}{l}\text { - Send identification } \\
\text { number } \\
\text { - Go physically - } \\
\text { using the code that } \\
\text { is send } \\
\text { - Fill forms with } \\
\text { details to identify } \\
\text { you } \\
\text { - Show ID pass } \\
\text { - Money is hand to } \\
\text { the person }\end{array}$ & $\begin{array}{l}\text { Differing experiences: } \\
\text { - Not easy - lot of } \\
\text { bureaucracy - identify } \\
\text { yourself with } \\
\text { ID/passport } \\
\text { - Easy }\end{array}$ & $\begin{array}{l}30 \text { minutes } \\
4 \text { hours } \\
3 \text { days }\end{array}$ & $\begin{array}{l}\text { High costs } \\
\text { Both sender and } \\
\text { receiver are charged - } \\
\text { highest costs - } 7 \%\end{array}$ \\
\hline Online Banking & $\begin{array}{l}\text { - Register online } \\
\text { banking with local } \\
\text { bank } \\
\text { - Send my account } \\
\text { number to the } \\
\text { other person } \\
\text { together with codes } \\
\text { - Receive the money } \\
\text { directly to the } \\
\text { account from their } \\
\text { account }\end{array}$ & $\begin{array}{l}\text { Needed an online dollar } \\
\text { account }\end{array}$ & 1 day & \\
\hline Paypal & $\begin{array}{l}\text { No specific } \\
\text { experiences }\end{array}$ & No specific experiences & $\begin{array}{l}\text { No specific } \\
\text { experiences }\end{array}$ & No specific experiences \\
\hline World remit & & $\begin{array}{l}\text { Easy instant remittance to } \\
\text { mobile phone }\end{array}$ & Few minutes & $\begin{array}{l}\text { Exchange rate is known } \\
\text { beforehand - 3\% of } \\
\text { entire amount }\end{array}$ \\
\hline Transfast & & $\begin{array}{l}\text { Easy instant remittance to } \\
\text { mobile phone }\end{array}$ & Few minutes & $\begin{array}{l}\text { Exchange rate is known } \\
\text { beforehand - 3\% of } \\
\text { entire amount }\end{array}$ \\
\hline Zoom & & $\begin{array}{l}\text { Easy instant remittance to } \\
\text { mobile phone }\end{array}$ & Few minutes & $\begin{array}{l}\text { Exchange rate is known } \\
\text { beforehand - } 3 \% \text { of } \\
\text { entire amount - this } \\
\text { one is cheapest }\end{array}$ \\
\hline ETF & & & Instant & \\
\hline Exchange houses & $\begin{array}{l}\text { You call to place - } \\
\text { and the money can } \\
\text { be immediately } \\
\text { picked up }\end{array}$ & Go to exchange house & Real time & \\
\hline
\end{tabular}


The preferences of the focus group participants are divers. The preferred way depends from region to region. Western Union is not easily accessible in rural areas, but it is a secure way of transferring money because of the proper verification system. Receiving money on mobile phone is also preferred as there is no need to have cash in pocket and it is quickly available. It is also private. E-Wallet is fast and secure: receiving money is only possible with a registered phone number. Another preference is Western Union in combination with M-Pesa in order to receive money in rural areas (already exist). Exchange rates with banks are open for debate when you have an account in KES and an account in USD. This also requires that you build up a relationship with your bank.

The available possibilities depend on the social class and the area where you live. People from the slums do not often go to the city. But on the other hand, there are no banks in slums.

A system that is not trusted by the focus group participants is post pay. It takes long and when the money is 'lost', it is very difficult to trace it. Other issues appear for instance when systems shut down, for instance due to maintenance that take place. Receiving money via third persons is a good option when there is no financial institution in the area. However, Kenya has a high financial penetration, because of M-Pesa, so there is not big need any more for money transfer via a third person. All focus group participants indicated that they experience positive changes in the international money transfer. It is going much faster compared to in the past. There is often also no physical effort needed anymore. And financial institutions are widespread, as for instance Western Union is even present in rural areas. They hope that in the future, systems can be improved by moving more to mobile money. They would like to know more about the different options to transfer money in terms of charges, efficiency, speed. It would be good to have applications that work from any phone - not only smartphones. 


\section{Blockchain technology}

Blockchain is embraced by the World Bank and the United Nations (https://un-blockchain.org). Within the scope of remittances, they encourage to decrease transaction costs and ease the transfer and as a result, overall access to money.

\subsection{What is blockchain technology?}

Blockchain is a decentralised governance system that could transform current structures for citizenship, authority and democracy (Atzori, 2015). It enables transactions without the need for intermediary parties such as banks or notaries. Blockchain is in particular interesting to employ it in situations where transactions are being hampered by distrust or improper governance.

The technology is in fact a database technology and is regularly acknowledged for its impact on reducing transaction costs, creating better provenance and improving on traceability and transparency (Baker \& Steiner, 2015). The two main characteristics of blockchain technology are:

- Firstly, blockchain offers true immutability of recorded data enabling transactions to be settled without the need for intermediary parties such as banks or notaries. It can be applied in situations where transactions are being hampered by distrust or unreliable governance.

- Secondly, this immutability feature can be applied with business logic using small programs called 'smart contracts', software which provides certainty on what exactly has transpired. A smart contract is an automated self-executing agreement between parties.

It is important to acknowledge that blockchain is a relatively new technology for which applications are still being developed and discovered. It is interesting to pilot and test, but it has not yet matured to the extent that would enable implementation in sensitive and essential business processes.

\subsection{Blockchain and cryptocurrencies}

Looking at cryptocurrencies could be a good start when considering blockchain in relation to remittance. One example of a cryptocurrency is the bitcoin. Bitcoin is a financial peer to peer transaction system developed by Satoshi Nakamoto in 2008. Bitcoin enables direct financial transactions without intermediary parties. This is an interesting development, especially where intermediary parties hamper financial transactions. For example when people cannot execute a transaction because they live in countries that are part of so called 'black lists'. These are countries that are deemed unreliable to Western banks, for example due to political instability. The bitcoin is a currency like the Dollar or Euro, but it is digital and distributed through a decentralised system (no central bank). Since the emerging of bitcoin, also other cryptocurrencies have emerged through the same type of blockchain technology.

It is suggested that blockchain can have major impact in the process of money transfers and changing the current process. Different tokens have been created to facilitate this process, which more or less follow the same rationale. This is an example by DPRG token (Decentralised Payment \& Remittance Gateway) from a conventional process: 


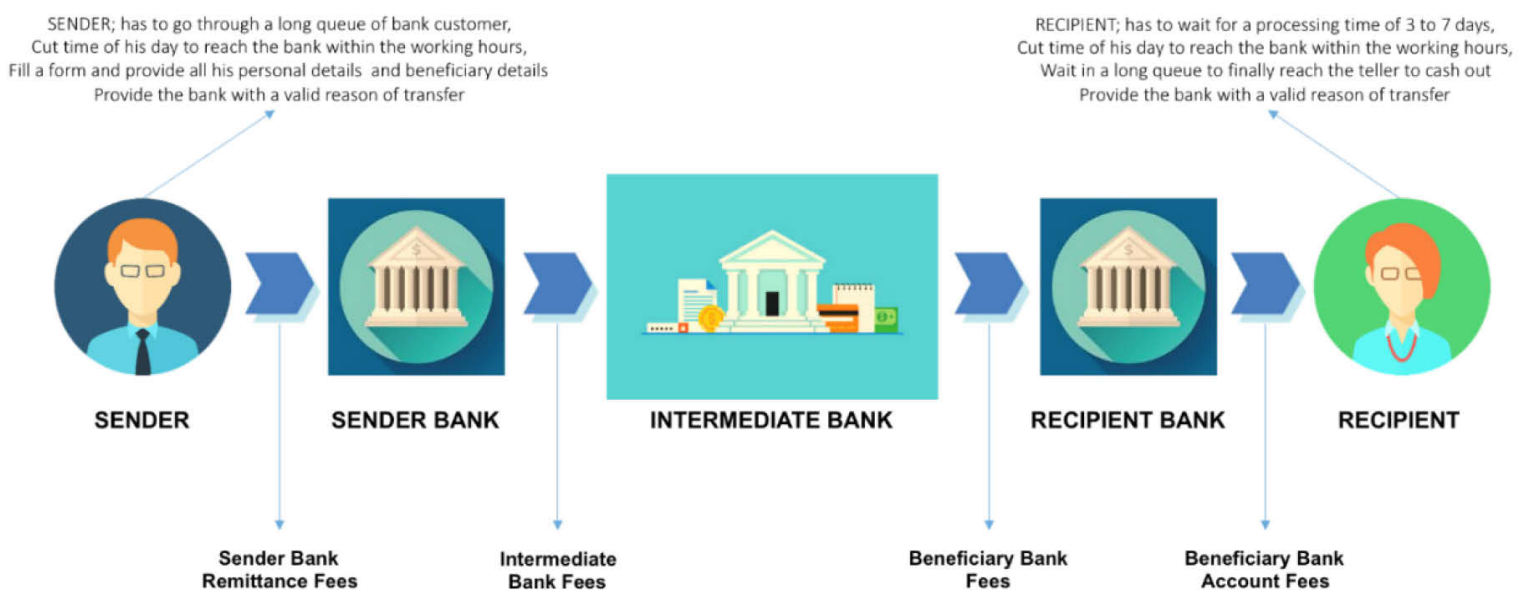

Into a process that is more direct without the need of intermediaries;

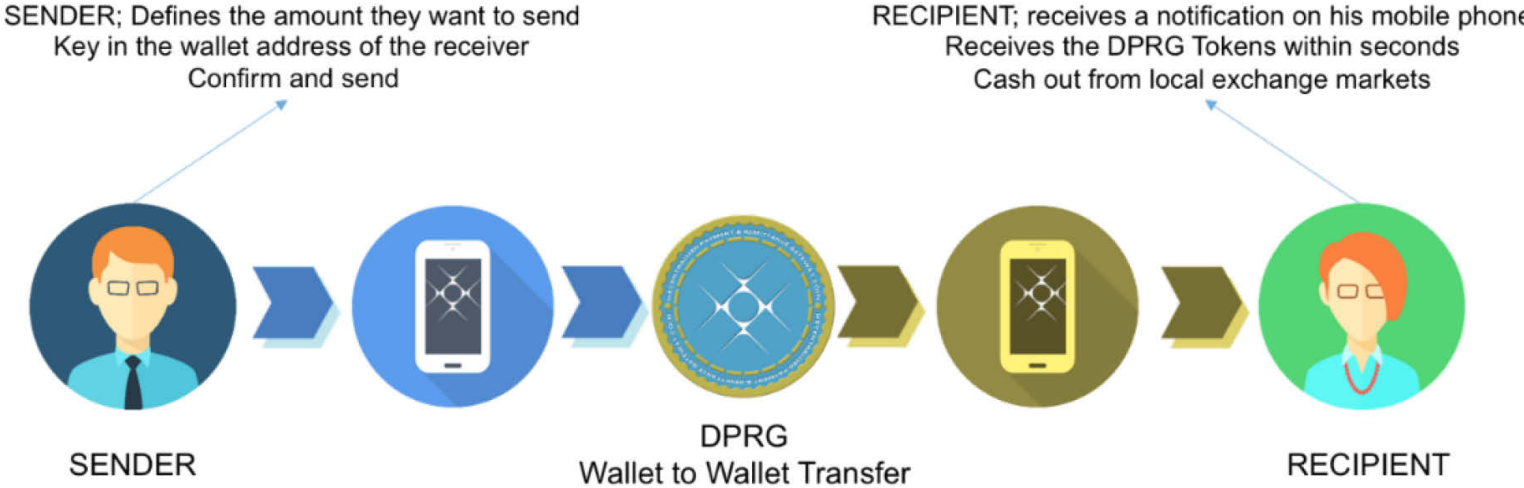

\subsubsection{Modalities to use bitcoin for remittances}

Bitcoin can be used for remittances in different ways (Biggs, 2016);

- By sending a bitcoin and receiving a bitcoin

- By sending a bitcoin and receiving a bitcoin which is changed into fiat currency

- By sending fiat currency which is changed in bitcoin which is received in bitcoin and changed into fiat currency.

The first way requires and adoption of the new technology by both the sending and receiving parties. But it creates a very direct money transfer without the need of intermediary parties. Typically, such a transaction can be executed in 10 minutes (Biggs, 2016).

The second and third way require some research into different types of intermediaries that can both exchange and send money. It is highly likely that this reduces the cost of the remittance, but other costs such as exchange and service costs may occur.

As exchanges, a marketplace where (crypto-)currencies can be traded, (dis)appear quickly and as the market is quite volatile and immature, it is difficult to say what a currency exchange would cost.

Examples of costs can be (Biggs, 2016):

\section{- Spread risk}

This is comparable to a gamble where a person speculates on a direction of price movement, makes a trade and calculates a profit or loss. 


\section{- Foreign xchange) rate (f/x)}

Like conventional money exchange, an exchange in cryptocurrency also involves exchange rates. In the situation where both the sender and receiver exchange, this exchange cost occurs twice.

\section{- Risk of loss}

In a way, cryptocurrency is comparable to cash money which needs to be kept safe. This involves costs for safekeeping like a safe, security etc.

\section{- Service costs/subscription fees/membership fees/KYC procedures}

Depending on the specific application (a platform, a mobile app) a provided service by an intermediary might be a paid service.

\section{- Transaction costs}

For any type of transaction on the open blockchain, the sender can decide on the transaction fees. The price of the transaction is the result of supply and demand and every transaction is equal, regardless the currency rate or the amount of the transaction itself. What matters is the number of satoshi per kilobyte for which the price is determined by the market. Scarcity exists because of the available space per block per 10 minutes.

\section{- Wallets to store coins are free}

Most exchanges are listed on CoinMarketCap which shows the volume rankings of each exchange. Examples with high volumes are CoinEx, Binance, or OKEx. This does not necessarily mean that these trades are true or meaningful trades. They could consist of 'empty trades' in order to generate traffic and volume. There are also exchanges that do not require exchange fees like BitMEX, CoinBene or Quoine. To exchange a EUR or USD for a popular coin like bitcoin is quite straightforward with many possibilities. More obscure coins and transfers to specific African currencies offers less choice. Some examples will be shown later.

Bitcoin is a relatively new currency and the receiving party aims to use the money for a specific goal. In the first situation this might be challenging as, especially in rural areas, spending cryptocurrencies might be difficult or impossible. Furthermore, ATMs where bitcoins can be deposited for cash and vice versa, are not common, let alone in these African rural areas. Biggs (2016) suggests bitcoin remittance service providers should create a local agent network, partnerships with existing networks and money service providers (like ATM networks, mobile money, traditional banks, cash transfer providers). Fees would be involved depending on the type of service.

As mentioned before; banks are struggling with cryptocurrency in combination with high standards such as 'know-your-customer' requirements. So far, bitcoin related activities are not fully defined or regulated. Illegal transactions are more easily facilitated by bitcoin and other (anonymous) cryptocurrencies. It is unclear how individual jurisdictions will react on this innovation; they might facilitate proper infrastructures but might also fully prohibit the use of these coins or tokens. Japan for example is choosing the route of regulation, China is opting for prohibition. In the second situation it is imaginable that bitcoin transactions will move to informal and illegal forms of transactions, comparable with current informal money transfers.

Biggs (2016) concludes by saying blockchain can represent significant cost reduction, reduction of barriers of geography and enabling new channels and pathways for interoperability of services and product offerings depending on adoption and interest, regulatory enablement, investment and collaboration.

\subsection{Decentralised and centralised blockchain applications for remittance}

Various initiatives have been launched for enabling remittances over blockchain. These new developments have been highly discussed in conferences and papers initiated by current market 
leaders and they are looking for ways to incorporate blockchain as well. The core essence of blockchain is decentralisation. However, if a conventional money transfer organisation takes on blockchain, it remains centralised per definition.

\subsubsection{Decentralised blockchain}

\section{Permission(less) ledgers}

Blockchain, the immutable data-structure that records bitcoin transactions, is also called a ledger, based on the idea that all participants in the network make a copy of the transactions and can review them like in a ledger. In the case of bitcoin, this ledger is permissionless; you do not need permission from any entity to be able to use it. It is also censorship resistant; no one can deny users of Bitcoin access to their possessions. There is no owner, anybody can download the software and participate in the network, review the transactions and choose a specific role. Anybody can become a miner for example (participation in the process of transaction verification), anybody can become user (someone who wants to have his transaction validated). This makes it a truly distributed system, whatever happened can be verified by anybody. Hence, the slogan 'don't trust, verify'. Furthermore, everybody is treated equally the system with regards to the KYC aspect. It is not necessary to provide any proof to your identity, your country of origin etc. The system facilitates a set of norms to which the users adhere.

A permissioned blockchain restricts the actors who can contribute to the consensus of the system, only some users have the rights to validate block transactions and creation of smart contracts might be restricted as well. Sometimes limited groups are allowed reading access. Actors need permission depending on the role they take on and this permission is granted by the entity creating the blockchain. Currently different organisations, especially centralised organisations such as banks, are interested in looking and testing this technology in a safe environment. After all, bitcoin offers the complete opposite of what the financial sector has established over the years; rules, standards, background checks, limited access etc.

\section{Overall some differences can be listed:}

\begin{tabular}{lll} 
& Permissionless & Permissioned \\
Access & Open & Authorised \\
\hline Speed of consensus & Slower & Faster \\
\hline Number of transactions & Lower & Higher \\
\hline Security/Consensus model & Proof of work/ proof of stake & Participants are vetted in advance \\
\hline Identity & Anonymous or Pseudonym & Known users \\
\hline Active & Built in/ native & Random / No activa
\end{tabular}

Blockchain is open, decentralised, peer-to-peer, borderless and permissionless which are core elements. Permissioned ledgers miss a lot of these advantages of blockchain and might face the disadvantages of a decentralised system. Furthermore, blockchain is a system that can be used for situations where trust in a third party is an issue. Usually within organisations that is not the case. However, it is of course understandable that the financial sector cannot yet fully adopt permissionless ledgers in their current forms. They have too much legislation to adhere to, and business processes and models in place. Furthermore, governments are not yet clear about their position on blockchains. The implications and consequences of blockchain are also not clear yet, thus implementation in essential business processes is not advisable. For now, both versions exist side by side.

\section{Problems with blockchain}

Cash money, mobile payments and cryptocurrencies can be used for illegal activities and are hard/impossible to track (Cecchetti and Schoenholtz 2017a). Obstacles to non-bank remittance service providers accessing payment system infrastructure, put in place to combat money-laundering and terrorist financing, are matters of concern. 


\subsubsection{Blockchain in a conventional, centralised process (based on http://ir.moneygram.com; Finextra Research, 2018; Simons, 2018)}

Existing conventional players in this field like banks and Money Transfer Organisations are working with permissioned ledgers. Consultancies and professional services also discover new business models where they design a permissioned blockchain, which can be applied in different professional settings. Other players that can start fully new business models based on this technology, work with both.

Alipay is an example that wanted to take over MoneyGram. Having failed to do so, they now are looking to demonstrate fierce competition. Alipay will launch blockchain based cross border remittance services, offering relatively low transaction fees between Hong Kong and the Philippines.

In the meantime, MoneyGram itself is trying the digital asset of Ripple (XRP) to use for cross border remittances. MoneyGram and Ripple are partners and will explore MoneyGram's integration into Ripple's ecosystem through $x$ Via. They focus on improving global treasury operations and consumer experience. Ripple is not meant to replace currencies, but to exist as a bridge between conventional currencies and crypto currencies. They focus on the financial sector, therefore on security and fast transactions. Ripple is however a centralised system; the initiators/company owns $70 \%$ of the coins and the network relies on 8 centrally maintained servers, this is a power force important to acknowledge as it could manipulate/influence price fluctuations.

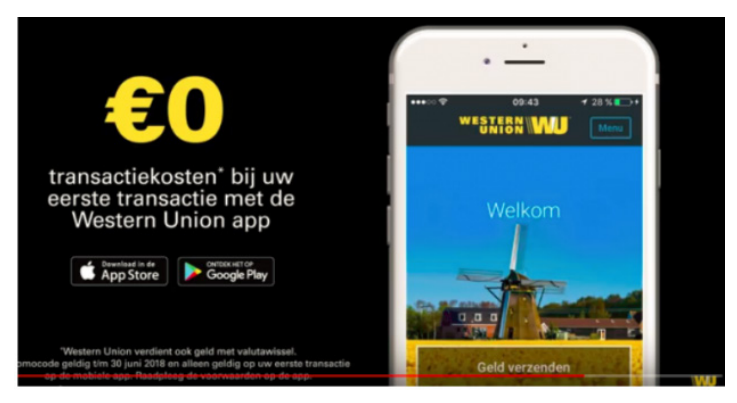

Western Union is also testing payments on the network of Ripple. In April 2021? they went live with an app for transactions for zero transaction fees. The Netherlands was first to receive this advertisement. It is not clear if this app runs on Ripple.

Ripple plans to partner with over half of the world's top banks within the next five years.

\section{Use cases}

In this volatile and new market, it is likely that new start-ups have been established and new coins have been launched by the time this document has been finalised. Many organisations focus on remittances over blockchain like:

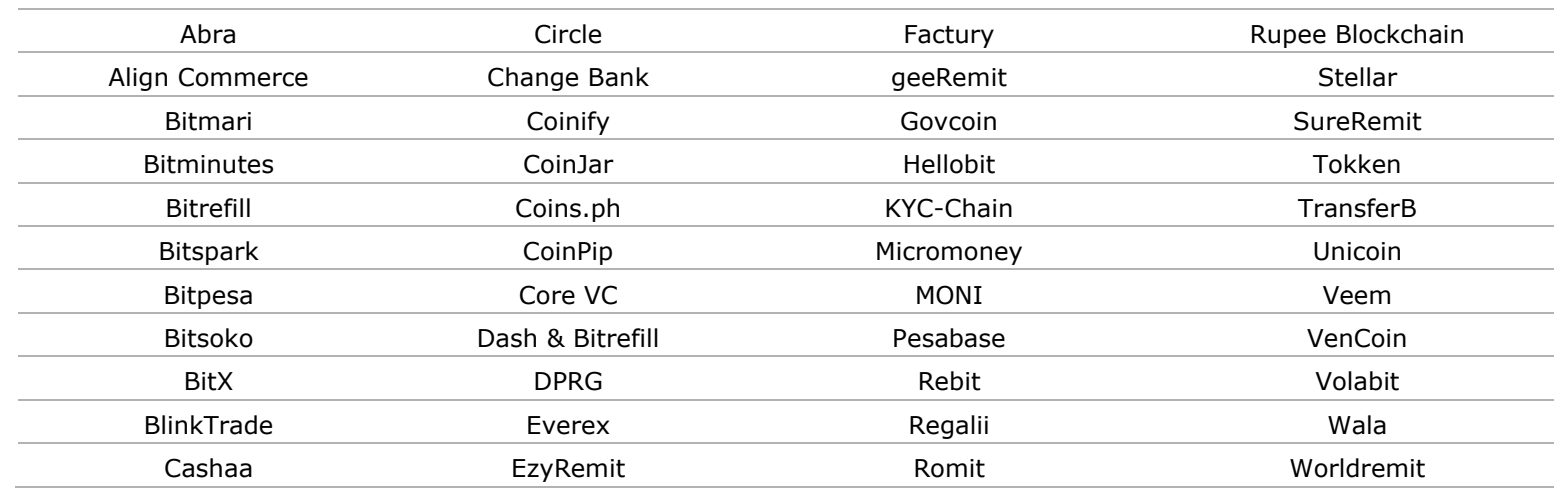


There are no rules for exchanges, ICO's and start-ups with regards to the information they have to provide. In that sense it is quite difficult to discover different elements that could be relevant such as the team behind the initiative, (de)centralisation of the network and nodes, the consensus algorithm, the community's behaviour and other elements.

\subsubsection{Global}

\section{Abra}

A global cryptocurrency app for buying, storing and investing in 25 different currencies. Also offers exchange from fiat to crypto. Users do not need a bank account and can send funds instantly to other users with a smartphone.

Token: Bitcoin --> decentralised, proof of work consensus

$\begin{array}{ll}\text { Founded } & 2014 \\ \text { Status } & \text { Active } \\ \text { Funded } & \text { Early Stage Venture } \\ \text { Type } & \text { For Profit } \\ \text { Funding } & 30,000,000 \text { USD }\end{array}$

\section{Romit}

This software allowed for instant transfers of cash in a way where customers do not have to deal with bitcoin themselves; a cash remittance solution through an app. A money transfer could be done via a kiosk, ATM or human cashier. They especially focus on sending smaller amounts (below 200 USD). The image on the right is a cost comparison that they made. It was one of the first players that used a blockchain ATM.

Romit does not longer exist, it seems as if they are moving towards traditional payments for mobile payments users, but it is unclear why they have stopped exactly.

$\begin{array}{ll}\text { Founded } & 2013 \\ \text { Status } & \text { Closed } \\ \text { Funded } & \text { Seed } \\ \text { Type } & \text { For Profit } \\ \text { Funding } & 125.000 \text { USD }\end{array}$

\section{Hellobit}

This is a remittance service based on bitcoin which targets emerging markets. Aside from remittance services it has another business model where anybody with a mobile phone can sign up as exchanger or delivery agent.

Process: a person signs up --> their background is checked --> they can earn bitcoin by delivering local currency to the recipients of the sent funds. A customer can send money to anyone worldwide, the receiver gets a text message when the funds are accessible.

$\begin{array}{ll}\text { Founded } & 1 \text { February } 2014 \\ \text { Status } & \text { Active } \\ \text { Funded } & \text { Seed } \\ \text { Type } & \text { For Profit } \\ \text { Funding } & 150.000 \text { USD }\end{array}$




\subsubsection{Africa}

\section{Bitpesa}

Focus on business; sending and collecting payments to and from Africa for small businesses.

Operates in Ghana, Kenya, Nigeria, Senegal, Tanzania, Uganda and DRC.

Application: platform

Offers 3 products:

1. BFX: cross border business to business payments in frontier markets

2. PESI: digital to fiat exchange for frontier markets

3. Remittance; which are KYC compliant, AML screening takes place. Money is transferred to bank and mobile money accounts.

$\begin{array}{ll}\text { Founded } & 1 \text { January } 2015 \\ \text { Status } & \text { Active } \\ \text { Funded } & \text { Early Stage Venture } \\ \text { Type } & \text { For Profit } \\ \text { Funding } & 10,000,000 \text { USD }\end{array}$

\section{Bitsoko}

Based in Nairobi, Kenya

Application: blockchain wallet/platform, token

Offers open-source mobile services for micro enterprises and SMEs. Encourages customers and merchants to adopt and use digital currency through their blockchain wallet. Merchants can buy or sell the tokens for loyalty programs or transactions.

Token: BITS (ERC-20)

$\begin{array}{ll}\text { Founded } & 1 \text { November } 2013 \\ \text { Status } & \text { Active } \\ \text { Funded } & \text { Early Stage Venture } \\ \text { Type } & \text { For Profit } \\ \text { Funding } & -- \text { (unclear) }\end{array}$

\section{Bitmari}

For sending money to Zimbabwe. It supports African indigenous languages.

Application: Mobile Wallet and the opportunity to earn commission on transaction fees through a referral program.

Process; sender has Bitmari account --> money transfer charged in bitcoins from app or site --> sent directly to destination --> recipient collects at selected outlet or local mobile wallet.

Token: Bitcoin 


\section{Social entrepreneurs in the agrifood sector Sub-Saharan Africa}

In this chapter, we explore the types of social entrepreneurs and their experiences to get access to finance. We also summarize the views on using blockchain to ease access to finance and other blockchain platform requirements or functionalities.

\subsection{Social entrepreneurs in the agrifood sector}

Social entrepreneurs have a business that aim to solve societal challenges. Social entrepreneurs can have different organisation models. They can be community projects, non-governmental organisations, cooperatives, social enterprises or businesses with a social purpose (dataroom, s.d.). Their legal status can be a private limited company, sole proprietorship, joint venture or capital venture (Quak, 2017).

In the agrifood sector, several types of social entrepreneurs can be identified (Quak, 2017):

- Social entrepreneurs in food production that give rural communities access to training, management tools and various kinds of inputs.

- Social entrepreneurs in food production that focus on environmentally friend and healthy food production.

- Social entrepreneurs in food processing and manufacturing that aim to add value by the processing and manufacturing of food to make sure poor farmers can expand their market.

- Social entrepreneurs in food distribution and marketing to ensure better deals for farmers and to open up new markets.

- Social entrepreneurs in food retail and consumption that aim to increase the access to healthy, ethical and organic food products by shops and other ways of providing the products to consumers.

- Social entrepreneurs that provide food knowledge to farmers and consumers in easy to access way in order to change their behaviour.

- Social entrepreneurs that in food finance that ease the access to finance for farmers like insurances or credit services

This typology is coming from an extensive global mapping of social entrepreneurs in the agrifood sector (Quak, 2017).

There are social entrepreneurs that work at the local level and want to create social value at the local level. These are called the Social Bricoleurs. There are social entrepreneurs that aim to create social value within regional or national boundaries. These are the Social Constructionists. And the social entrepreneurs that create value at the transnational or global context are called the Social Engineers (Smith and Stevens, 2009). In other words, the social entrepreneurs can operate at different levels.

\subsection{Access to finance}

Comparable to conventional entrepreneurs, social entrepreneurs also follow a business growth in 3 stages:

- Start-up stage

- Growth stage

- Mature stage

A large number of social entrepreneurs struggle with finding finance to invest in their business. The start-up stage is therefore expected to be much longer, compared to conventional entrepreneurs. Many social entrepreneurs are in the start-up stage often purely donor-driven (Quak, 2017). And many remain partly donor-driven during the lifetime of their business (Quak, 2017). The focus group participants 
mainly indicated that finance was needed to set-up equipment and the office, to finance permits and licences, for marketing, for digital presence and online infrastructure, for buying land. In other words, the investment needs are comparable to conventional entrepreneurs. But the time needed before making profit is longer compared to conventional entrepreneurs, was argued during the focus group. A social entrepreneur needs on average 2 to 3 years before making income and profit. Finance is sought through various channels (focus group and Quak, 2017):

- Loans and finance from family and friends nearby

- Donation from diaspora

- Micro-finance

- Crowdfunding

- Angel investors

- Capital ventures

- Loans and credit from banks

- Impact investors: private funds, high level individuals with a lot of money that want to generate impact

- Grants

- Shylock: you can get money but at a very high interest at a very short time

- Loans from Sacco's and cooperatives

- NGO that finance or support your business

- Charity from donor organisations

- Doing odd jobs to collect the money

- Project funding from governments or NGO's

The focus group participants indicated that easy to access money is:

- Loans from Saccos, but you have to be a contributing member. They will give you up to 3 times your savings and you can negotiate the payback period.

- Government funds like national subsidies for innovation. Or environmentally aligned innovations.

- Family and friends because they know you and they trust you and understand your business.

- Grants but there is high competition

- Impact investors - but they want to get into a business with good financial prospects, the right market and government issues sorted out. And it needs to create impact and generate value that goes back to them.

Sometimes, social entrepreneurs do not get the money, but they get in kind support by raw materials. The product can be made and sold and then part of the profit can go back to the person that brought in the materials.

We explored the types of funds that are considered as difficult to get access to, or difficult to fit with the businesses. These funds are:

- Loans from banks

- The shylocks

- Subsidies

The difficulty to get access to these types of funds are related to:

- The short time that they have to pay back a loan, the high interest rates, the long time needed before making profit

- The lack of proof of concept/case study: people do not see the benefit or do not belief in the concept

- The stigma on the social group they work with

Social entrepreneurs also receive remittances. However, this can also be difficult: if people at the other side trust you, they will easily give money. Otherwise it is more difficult. There is a Kenya diaspora alliance. You need another person or an organisation to bring you in touch with the diaspora. It is needed to have this connection. They understand where you come from and they understand what your problems are. When it comes to receiving money from remittances, the most preferred ways are:

- M-Pesa

- Via the bank

- Cash - because no transaction costs

- Sendwave - to send money to your phone without MG or WU

- Forex 
When accessing funding, social entrepreneurs are asked to provide specific information. During the focus group, the information requirements for each funding mechanisms were identified (Table 2).

Table 2 What information is required to get access to finance and who needs this information?

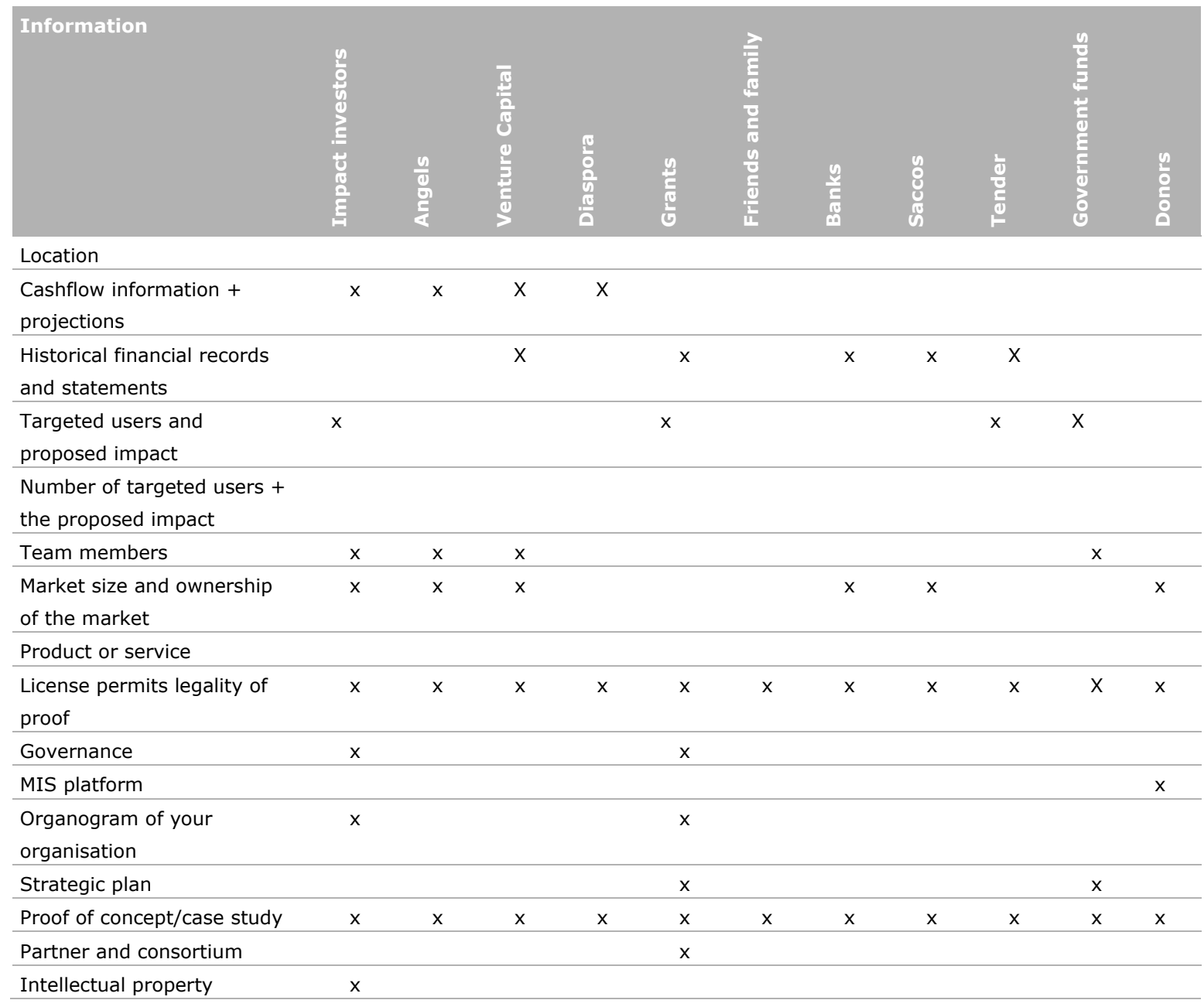

\subsection{Views on blockchain technology as a way to receive funding and related information provision}

The blockchain technology was discussed in the two focus groups (people receiving remittances and social entrepreneurs in the agrifood sector). Not all people in the focus groups were familiar with blockchain technology. For most of the people involved, the concept of blockchain technology was new. There are several associations with blockchain technology in the focus groups:

- A complex information system that is owned by no one and that is accessible to everyone within the chain.

- Information that cannot be stolen, very accountable.

- It is like a bank that holds money till a task is completed, then it releases for various projects that relate to the company.

- Shared digital ledgers used in securing different types of transactions.

- Used in payments and in contracts.

- It stores records.

- Shared digital agent - different types of information and transaction - to use for accountability in various sectors: banks, schools.

- It creates transparency. 
What is the downside of it?

- We still have some issues about the other side of the web to trust the system.

- Blockchain is associated with cryptocurrency and some people are scared of cryptocurrency. It is not known whether this is legal.

To explore their views on the blockchain technology, we made three propositions to explore their position.

One proposition was about the amount of money received via blockchain and the requirement to spend it only to the purposes that are attached to receiving the money. Half of the people receiving remittances are fine with receiving money that is intentionally allocated to specific purposes. The other half prefers to receive less money in return for freedom to spend to purposes they define themselves. This is mainly to be flexible to meet the needs that are actually experienced in the community. Earmarking money may result in problems not being addressed adequately. Also, half of the group of people receiving remittances was okay with clarifying where the money was used for.

The second proposition was about transaction costs and the use of cryptocurrency to decrease transaction costs. The majority of both focus groups is in favour of reducing transaction costs as much as possible but there is doubt whether cryptocurrency is going to be accepted. Some people in the focus group of receivers of remittances doubt the rates of cryptocurrencies are stable. And there is some hesitance to rely on cryptocurrency with regard to lack of legislation and it is not sure if it is legal. Not all participants of both focus groups are familiar with cryptocurrency and how it works. There may be people that are not aware of it and may be even be scared of it. Kenya has the application M-Pesa which is very well introduced and widely accepted so it would make more sense to make use of M-Pesa rather than cryptocurrency and to open up M-Pesa for international money transfer.

The third proposition was about the willingness to reveal information about the person and potentially the business in order to build trust and decrease donor risks. Receivers of remittances were fine with providing information demography, location and gender. Receivers of remittances are not keen on having this information shared with others than the donors of the remittances. The focus group of social entrepreneurs indicated that they were fine with revealing information on their business. However, the social entrepreneurs indicated that they would have been confronted with the following dilemma:

"The issue of trust comes in because you cannot really talk with the investor via such an open platform. You can not reveal too much, otherwise someone else steals your idea. But if you do not tell, you will also not find investors".

Therefore, we can conclude that the blockchain platform should enable some interaction and trust building mechanisms to help the business grow.

The group of social entrepreneurs were more willing to reveal different types of information, mainly because they want to create trust and proof that they are accountable. The social entrepreneurs have indicated during the focus group that they are willing to provide the following information:

- Name

- Picture - not all people want that

- Education - but the question is - is this relevant - maybe some investors want to provide training if you lack some

- Age: important because it matters if someone is below 18 -27 - in order to handle the money carefully

- Gender: is okay - but not relevant

- Location is okay but then at county level - not willing to mention the village in order to get the investment. Location may be sensitive information.

- Credit score is okay to build trust and accountability

- Biomedical data: not willing to share - people are scared that it will be abused

- On what the money has been spend: is okay.

- Income from the business: is okay - this is public information anyway

- Reference information 
More difficult is information that is part of the business plan:

- Market size - though the information might not be up-to-date

- In the beginning providing financial data is difficult

- In the beginning, providing a strategic plan is difficult as well

- Intellectual property is a long and extensive process

Showing impact is not difficult because it is part of the business plan, and a social entrepreneur sincerely thinks about it continuously. However, measuring the impact is not easy for everyone. There is a need for support.

We can conclude that when social entrepreneurs are funded, for instance by diaspora, there is a willingness to pay back the money to investors. Payback might be possible after 2 years, as indicated by the social entrepreneurs. However, the preference is to work with equity and have more mutual communication between entrepreneur and the investor. Another preference is via philanthropy because than there is no pressure to give the money back. However, the philanthropist wants to have information on the social impact. There is a need to develop systems to trace back the social impact.

\subsection{Existing platforms to finance social entrepreneurs}

Today, social entrepreneurs are able to get access to international and national funding via platforms. Platforms like business for Africa where investors can choose a business already exist. These examples include a kind of competition and helps to connect with investors. You do not have to look for each individual investor.

- Crowdfunder - https://www.crowdfunder.com/ - a platform to promote a product or service to get funds from the crowd.

- Chuffed - https://chuffed.org/ platform for projects with a social cause

- WeFunder - https://wefunder.com/ - platform where you can invest in start-ups.

- Starts Some Good - https://startsomegood.com/ - StartSomeGood is a cause-driven crowdfunding site

- eOpportunities - https://eopportunities.org/ - to link investors to investment opportunities in Kenya

- LelapaFund - https://www.lelapafund.com/ to connect private investors with business in Africa

- VC4A - http://VC4A.com

- Wajenzi - a crowdfunding platform promoting migrants' investment in SMEs in emerging countries

- AFRIKSTART: https://www.afrikstart.com/

There are already online platforms where investors and donors meet entrepreneurs. However, blockchain technology is not yet integrated. The social entrepreneurs in the focus group made to following suggestions in case a blockchain related platform would be built:

- To include functionalities that indicate the progress of the business over the past years.

- To include business to business collaboration as well - to find people that can help with the business growth

- To include specific functionalities to reach out to funders: by being able to reveal the current challenge and have a discussion with others for advice and opinion and maybe also receiving equipment. 


\section{Conclusion}

Given the exploration of relevant aspects with regard to using block chain technology as way to finance social entrepreneurs in Kenya (and other African countries) by means of remittances, we can conclude and answer the key questions in this study:

\section{What is the potential of funding coming from the remittances of the diaspora?}

- Diaspora are willing to send remittances to reduce poverty and strengthen the competences of local people and to invest in real estate. They are even willing to invest in other areas than their hometown but the issue is to find reliable people to invest in. Remittances that is provided to social entrepreneurs is mainly considered as an investment by the diaspore, requiring at a certain point a return of investment or even pay back.

- If block chain technology is able to reduce current transaction costs, diaspora is willing to revert a percentage of the saved costs to social entrepreneurs. Since the World Economic Forum (2015) estimated that a reduction of transaction costs for Sub-Saharan Africa to the global average would mean an extra 1.3 billion USD added to the existing remittances. Even if only $20 \%$ of the saved transaction costs would be reverted to social entrepreneurs, this approach would unlock 260 million USD for social entrepreneurs.

\section{What are current financial challenges when sending money?}

In order to be able to enter the market of international money transfer, the blockchain technology should overcome currently experienced challenges and should be in line with the incentives of the different stakeholders to use it:

- Decrease international transaction costs,

- Increase transparency of international money flows - especially with regard to the receiver of the money,

- Decrease risk of losing the money,

- Making sure that the system is accessible by all social groups, including people living in rural areas or slums,

- Avoid distorting effects in the local community,

- Increase speed of international transfer - however, there are already options that enable money transfer in just a few minutes,

- Easy to use: avoid too much bureaucracy to unlock the money and avoid having to get out of the house to get the money.

What are the current challenges of social entrepreneurs with regard to financial support? The blockchain technology should provide the option to social entrepreneurs to pay back the investment at a slower speed, compared to loans from banks. Many social entrepreneurs are only able to pay back after 2-3 years. They often also need financial support in the later stages of their business.

\section{What are the views of the different stakeholders on the current challenges and the potential} of block chain technology?

The diaspora would see the potential in the blockchain technology as a way to provide information on reliable social entrepreneurs and to make sure the remittances are well spent. In both focus groups in Kenya, there was an interest to explore blockchain technology as a way to attract funds for their business. But they also mentioned several other online money transfer that already exist but that many people are not aware of yet. It may be worth to improve information provision on existing online money transfer systems rather than building new systems according to the focus groups. They also mentioned that there already existing online platforms for entrepreneurs to each out to international donors. There is also a quite sceptical view on the use of cryptocurrency. People do not really know if it is legal and how it works. Therefore, we conclude that the blockchain technology could be worth to explore and develop via trial and error but will be confronted with strong competition from existing systems and platforms. 


\section{What are the conditions that diaspora (would) set, when transferring money to social entrepreneurs via blockchain?}

The diaspora wants to know if a person is reliable. They have indicated that this reliability can be revealed when the following information is provided:

- return on investment,

- the social aspect of the enterprise,

- how the investment will help the entrepreneur,

- the legitimacy of the founder or the entrepreneur,

- whether the organisation is a cooperative,

- the employment that will be created,

- the poverty that will be reduced and other environmental benefits,

- annual financial statements,

- information about governance,

- history of the company,

- the involved team,

- information about the product.

The information should be easily accessible, and the impact should be clear. Overall, getting trust that the investment will be well spend, is a very important element for diaspora. Provision of the proper documents, and perhaps even guarantees, can help to mitigate the (perceived) risks.

\section{What information provision has to be part of the blockchain concept?}

Blockchain helps to improve transparency and build trust. When comparing the request for information from the diaspora on the one hand and the willingness to reveal information on the side of the social entrepreneurs, we observe that there is more dialogue needed to match the information needs and the willingness to reveal information. Diaspora mainly want to know more about the business itself while the social entrepreneurs are confronted with the dilemma to reveal information, while protecting the core idea of their business to avoid that others take over. This is a though dilemma that should require more dialogue to come up with the required information sheet to include in the blockchain technology. However, both parties are very much interested to show the social impact and added value but are lacking easy to apply monitoring methods and presentation methods to provide this social impact information.

\section{To consider before starting the development of the blockchain technology:}

- Necessity: Sometimes automation will do, blockchain is not always necessary. It needs to be a clear case how social entrepreneurs are benefited through a blockchain solution for crowdfunded remittances compared to a normal platform for these types of investments. We have not yet found this necessity niche in the context of Kenya.

- Context: Depending on the country of recipients, ways of payments, rural versus urban areas, applications might differ. Kenyans for example are used to mobile payments through M-Pesa which might lead to a different type of solution compared to a person from a rural area who wants to receive cash.

- (De)Centralisation: Currently all money transfers happen through centralised systems which create the transaction costs. It would make sense to choose a decentralised system, but if it is necessary to create a business model, this requires more thought. A permissioned ledger might be more suitable for a fast, safe, and controlled pilot, but a permissionless might lead to a more realistic and futureproof solution.

- New versus Existing: Various remittance applications exist already, perhaps one of them could be applicable for this project. If not; a new token might be created which needs a thorough thought and design process as well.

- Process: Some actors will have things to gain from decentralisation whilst others might not. Consider picking specific actors along the chain of the remittance process for design of the application.

- Role of the donor: is this an investor that will get a return of investment or is it a philanthropist who donates the money? This will result in different types of information requirement. 
- How to get the social entrepreneurs involved to the blockchain technology: SES4FOOD is having linking pins in various African countries that would play a role in mobilising the social entrepreneurs to join the block chain platform.

To conclude: Blockchain is disrupting the market of remittances with cryptocurrencies, giving way to new start-ups, but also for conventional money transfer organisations to rethink their processes and business models. It is not clear what the exact implications of blockchain technology are in the remittance markets, but it would be worth to further explore the application of blockchain via a trial and error process, where we learn from other initiatives. 


\section{References}

Aalbers, C., Ten Hove H., van der Pijl M., (2019) Leveraging embassy food security programmes with social enterprise opportunities. Food and Business Knowledge Platform. 29p.

Atzori, M. (2015). Blockchain Technology and Decentralized Governance: Is the State Still Necessary? SSRN Electronic Journal.

Baker, J., \& Steiner, J., (2015). Provenance Blockchain: the solution for transparency in product [online] Provenance.

Bekkers, R., Schuyt T., Gouwenberg B., (2017) Geven in Nederland 2017. Huishoudens, nalatenschappen, fondsen, bedrijven, goede doelenloterijen en vrijwilligers. http://www.geveninnederland.nl/wp-content/uploads/2017/10/GIN-2017-voorkant-ensamenvatting.pdf

Biggs, D. C., (2016). How non-banks are boosting financial inclusion and remittance. In Banking Beyond Banks and Money(pp. 181-196). Springer, Cham.

CBS, (2018). Bevolking naar migratieachtergrond. [online] Available at: https://www.cbs.nl/nl$\mathrm{nl}$ /achtergrond/2016/47/bevolking-naar-migratieachtergrond [Accessed 3 Jun. 2018].

Cecchetti, S., Schoenholtz K. (2018) Voxeu.org. (2018). The stubbornly high cost of remittances | VOX, CEPR Policy Portal. [online] Available at: https://voxeu.org/article/stubbornly-high-costremittances [Accessed 15 June. 2018].

Durand, J., \& Massey, D. S. (Eds.). (2004). Crossing the border: Research from the Mexican migration project. Russell Sage Foundation.

Finextra Research, (2018). Alipay takes on MoneyGram with blockchain-based remittances. [online] Available at: https://www.finextra.com/newsarticle/32304/alipay-takes-on-moneygram-withblockchain-based-remittance-programme?utm_medium=newsflash\&utm_source=2018-625\&member $=87147$ [Accessed 29 Jun. 2018].

IBRD/IDA, (2016). Getting SmaRT about remittance price monitoring Methodology for the Smart Remitter Target (SmaRT): a new approach to measuring the progress towards the global objectives of reducing the cost of international remittances, Payment Systems Development Group June 2016

IFAD, (2017) Sending Money Home. Contributing to the SDGs, one family at a time. IFAD. https://www.ifad.org/documents/38714170/39135645/Sending+Money+Home++Contributing+to+the+SDGs\%2C+one+family+at+a+time.pdf/c207b5f1-9fef-4877-9315$75463 f c c f a a 7$

International Bank for Reconstruction and Development (IBRD) / The World Bank, (2014). Report on the Remittance Agenda of the G20, Financial Inclusion and Infrastructure Global Practice

IOM, (2014). The impacts of remittances on the economy of developing countries. http://www.europarl.europa.eu/document/activities/cont/201403/20140326ATT81850/20140326A TT81850EN.pdf

Medici, (2018). 11 Money Transfer Companies Using Blockchain Technology. [online] Available at: https://gomedici.com/11-money-transfer-companies-using-blockchain-technology-2/ [Accessed 1 Jun. 2018].

Nvgtk.nl. (2018). NVGTK - Nederlandse Vereniging Geld Transactie Kantoren - Welkom. [online] Available at: https://www.nvgtk.nl/home/ [Accessed 10 Jun. 2018].

Oyinloye A., (2018). Africa remains the most expensive for remittances [Business Africa] [online] Available at: http://www.africanews.com/2017/06/22/despite-reduction-in-cost-of-remittancetransactions-africa-remains-the-most/ [Accessed 1 Jul. 2018].

PWC, (2015). De succesfactoren van een sociale onderneming. https://www.pwc.nl/nl/assets/documents/pwc-de-succesfactoren-van-een-socialeonderneming.pdf

Quak, E.-J., (2016). Actions between profit-making \& aid: improving social entrepreneurship for food security. New insights through bottom-up and interactive mapping approach. http://knowledge4food.net/wp-content/uploads/2017/04/170216_report-socialentrepreneurship_printDEF.pdf 
Ratha, D., Mohapatra, S., Ozden, C., Plaza, S., Shaw, W., \& Shimeles, A., (2011). Leveraging migration for Africa: Remittances, skills, and investments. Washington DC: The World Bank.

Simons, W., (2018). Western Union test betalingen op ripple-netwerk. [online] Bitcoin Magazine. Available at: https://bitcoinmagazine.nl/2018/02/western-union-test-betaling-ripple-xrp/ [Accessed 27 Jun. 2018].

Smith and Stevens, (2010). Different types of social entrepreneurship: the role of geography and embeddedness on the measurement and scaling of social value. In: Entrepreneurship \& Regional Development. 22 (6). Pp. 575-598.

Smits, H., (2005). Pinoleros aquí, pinoleros allá, Een onderzoek naar (e)migratie en remittances in León, Nicaragua, Afstudeerscriptie Taal- en Cultuurstudies Universiteit Utrecht Oktober 2005

The Guardian, (2016). Remittances three times greater than aid SDGs. [online] Available at: https://www.theguardian.com/global-development-professionalsnetwork/2016/may/11/remittances-three-times-greater-aid-sdgs [Accessed 6 Jun. 2018].

Toptal Finance Blog, (2018). How Is the International Money Transfer Market Evolving? [online] Available at: https://www.toptal.com/finance/market-research-analysts/international-moneytransfer [Accessed 6 Jun. 2018].

World Bank Group, (2017). Migration and remittances, Recent Developments and Outlook Special Topic: Global Compact on Migration, Migration and Development Brief 27 April 2017

World Bank Group, (2017). Migration and remittances, Recent Developments and $\backslash$ Outlook, Transit migration, Migration and Development Brief April 2018

World Bank Group, (2018). Remittance prices [online] Available at: https://remittanceprices.worldbank.org/sites/default/files/rpw_report_december2017.pdf [Accessed 1 Jul. 2018].

World Economic Forum, (2018). Why we need to cut remittance fees now. [online] Available at: https://www.weforum.org/agenda/2015/03/why-we-need-to-cut-remittance-fees-now/ [Accessed 12 Jun. 2018].

\section{Other helpful websites}

- https://www.abra.com/

- https://www.bitmari.com/core/

- https://bitsoko.co.ke

- https://coinmarketcap.com

- https://www.crunchbase.com

- https://www.dataroom24.com/exploring-social-entrepreneurship/

- https://www.gwktravelex.nl

- https://www.ing.nl/particulier/betalen/tarieven/buitenland/index.html

- https://www.investopedia.com

- http://knowledge4food.net

- http://www.martijnbolt.com

- http://ir.moneygram.com

- https://www.paypal.com/nl

- https://public.bitpesa.co/

- https://socialfoodentrepreneurs.ushahidi.io/views/map

- https://transferwise.com/pricing

- https://www.dataroom24.com/exploring-social-entrepreneurship/ 


\section{Annex 1 List of interviewed persons}

Elizabeth Njeru, in the Netherlands, 25 September 2018

Charles Vanderpuye, in the Netherlands, 3 September 2018

Benjamin Dzilah, in the Netherlands, 17 September 2018

Alain Nkurikiye, in the Netherlands, 6 June 2018

Michiel Berende, in the Netherlands, 6 June 2018

Martijn Bolt, in the Netherlands, 6 June 2018

Jana Petkanic van Ethichub in Netherlands, 16 November 2018 
Wageningen Environmental Research P.O. Box 47

6700 AA Wageningen

The Netherlands

$T+31(0) 317480700$

www.wur.nl/environmental-research

Wageningen Environmental Research Report 3083

ISSN 1566-7197
The mission of Wageningen University \& Research is "To explore the potential of nature to improve the quality of life". Under the banner Wageningen University \& Research, Wageningen University and the specialised research institutes of the Wageningen Research Foundation have joined forces in contributing to finding solutions to important questions in the domain of healthy food and living environment. With its roughly 30 branches, 6,500 employees (5,500 fte) and 12,500 students, Wageningen University \& Research is one of the leading organisations in its domain. The unique Wageningen approach lies in its integrated approach to issues and the collaboration between different disciplines.

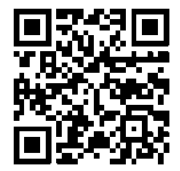





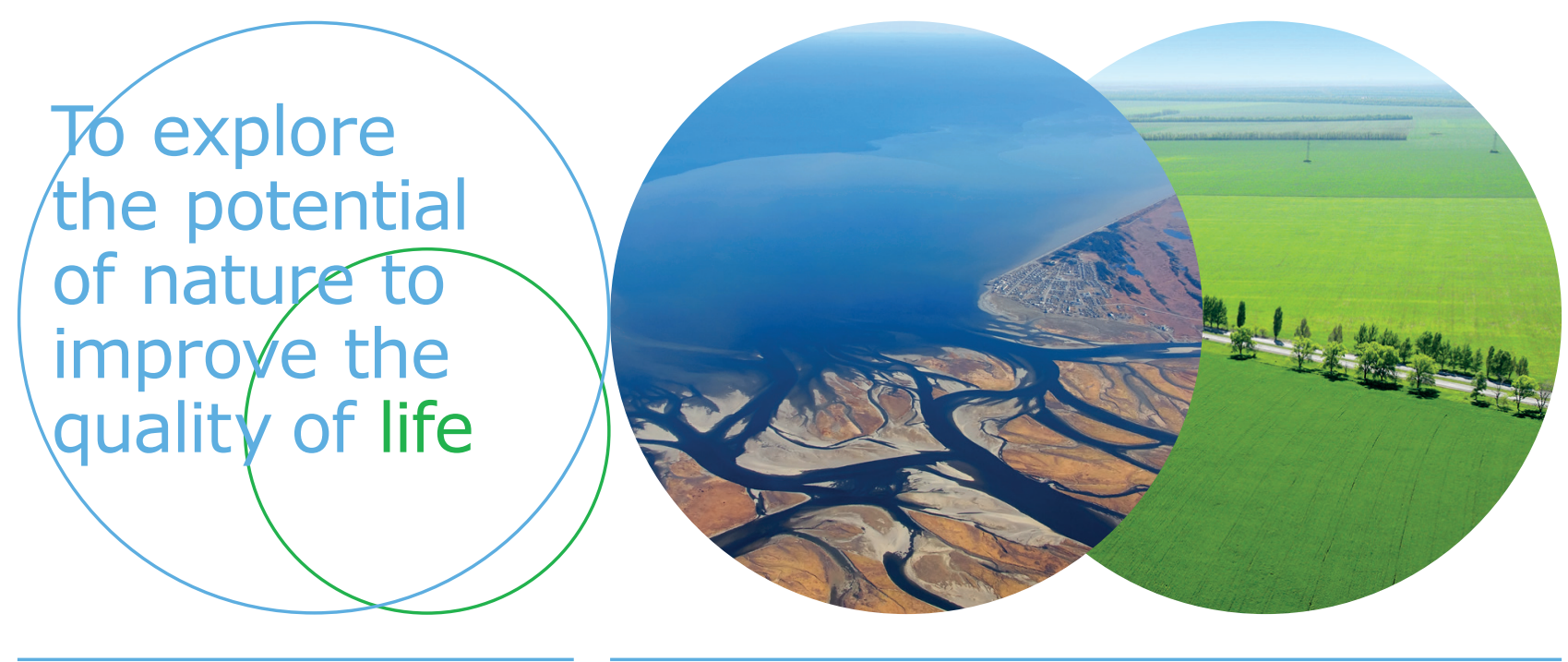

Wageningen Environmental Research P.O. Box 47

$6700 \mathrm{AB}$ Wageningen

The Netherlands

$T+31(0) 317480700$

www.wur.eu/environmental-research

Report 3083

ISSN 1566-7197
The mission of Wageningen University \& Research is "To explore the potential of nature to improve the quality of life". Under the banner Wageningen University \& Research, Wageningen University and the specialised research institutes of the Wageningen Research Foundation have joined forces in contributing to inding solutions to important questions in the domain of healthy food and living environment. With its roughly 30 branches, 6,500 employees (5,500 fte) and 12,500 students, Wageningen University \& Research is one of the leading organisations in its domain. The unique Wageningen approach lies in its integrated approach to issues and the collaboration between different disciplines. 